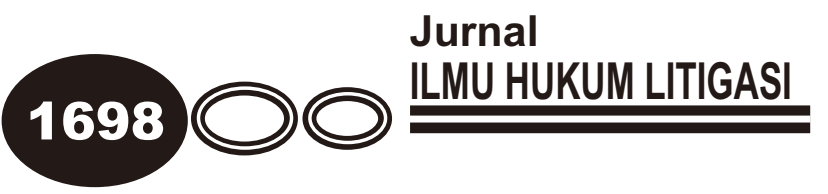

\title{
REKONSEPTUALISASI HAK ATAS TANAH DALAM KERANGKA PEMBAHARUAN HUKUM TANAH NASIONAL
}

\author{
ILYAS ISMAIL, SUFYAN \& AZHARI
}

Dosen Fakultas Hukum Universitas Syiah Kuala, Jalan Putroe Phang No. 1 Kopelma Darussalam Banda Aceh, Telp. 0651-7552295, Fax. 0651-7552295, email: ilyas.hukum@gmail.com, nyaksufyan@yahoo.com, azhari_husen@yahoo.com.

\begin{abstract}
ABSTRAK
Tulisan ini dimaksudkan untuk menjelaskan mengenai macam-macam hak atas tanah yang dikenal dalam ketentuan perundang-undangan, pelaksanaan berbagai macam hak atas tanah tersebut dan rekonseptualisasi hak-hak atas tanah dikaitkan dengan restrukturisasi penguasaan tanah. Untuk mendapatkan data bagi kepentingan penulisan ini dilakukan penelitian kepustakaan dan penelitian lapangan. Penelitian kepustakaan dilakukan dengan cara menelaah ketentuan perundang-undangan dan literatur yang relevan, sedangkan penelitian lapangan dilakukan dengan cara mewawancarai para nara sumber yang terkait. Hasil penelitian menunjukkan bahwa paling tidak terdapat 13 (tiga belas) macam hak atas tanah yang terdapat pengaturannya dalam ketentuan perundang-undangan. Sebagian besar hak-hak atas tanah tersebut bersumberkan pada hukum adat yang berkonsepsi kumunalistik. Namun diantara hak-hak atas tanah tersebut dalam pelaksanaannya ada yang masih mengandung unsur pemerasan, cenderung semakin meningkatkan ketimpangan dalam penguasaan tanah dan cenderung tidak dapat mengakomodir kebutuhan tanah yang semakin komplek dalam keterbatasan ketersediaannya, karena itu diperlukan rekonseptualisasi hak-hak atas tanah.

Kata kunci: Rekonseptualisasi, Hak Atas Tanah, Pembaharuan Hukum.
\end{abstract}

\section{ABSTRACT}

This paper is going to discuss the sorts of land rights recognized by laws and the implementation of such rights and recopceptualisation related to the land reform program. Library and field researches are conducted to obtain the data. Library research is conducted by exploring the relevant laws and literatures while field research is conducted by interviewing relevant informants. The research shows that there are about 13 rights of the land that can be found in the regulations. Most of the rights on land is based on customary law which has communal concept. However, amongst such rights in the implementation still faces unjust in dividing its benefit, there is a tendency to increase the gap in owning the land and to disobey the need of housing that more complex in the limited number of it; hence the reconceptualisation is required for the rights.

Keywords: Recopceptualisation, Land Rights, Law Reform. 


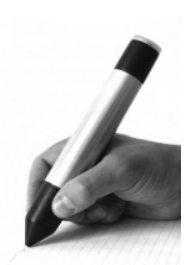

\section{PENDAHULUAN}

Tujuan utama hukum agraria nasional sebagaimana ditentukan dalam Undang-Undang Nomor 5 Tahun 1960 tentang Peraturan Dasar Pokok-Pokok Agraria (biasa juga disebut Undang-Undang Pokok Agraria dan untuk selanjutnya disebut UUPA) meliputi tiga hal, salah satunya adalah meletakan dasar-dasar untuk mengadakan kesatuan dan kesederhanaan dalam hukum pertanahan. Hal ini dilatarbelakangi oleh adanya dualisme hukum tanah pada masa kolonial maka berdasakan UUPA diciptakan unifikasi hukum dalam bidang pertanahan dengan berlandaskan pada hukum adat.

Undang-Undang Pokok Agraria dan ketentuan perundang-undangan lainnya menentukan macam-macam hak atas tanah. Hak-hak atas tanah dimaksud, di samping tidak semuanya berdasarkan pada hukum adat, juga cenderung tidak mencerminkan kesederhanaan hukum pertanahan khususnya mengenai struktur hak-hak atas tanah.

Hak Sewa, Hak Usaha Bagi Hasil dan hak-hak lain yang bersumberkan pada hukum adat yang dalam kenyataannya tidak terdaftar mengindikasikan hakhak tersebut tidak efektif dan juga cenderung menimbulkan permasalahan dalam pelaksanaannya. Di samping itu pengaturan Hak Guna Usaha dan Hak Guna Bangunan serta Hak Pengelolaan dalam hukum tanah nasional sekarang ini cenderung menimbulkan permasalahan dalam sistem hukum tanah nasional. Karena itu struktur hak atas tanah sekarang ini sebagaimana terdapat dalam 


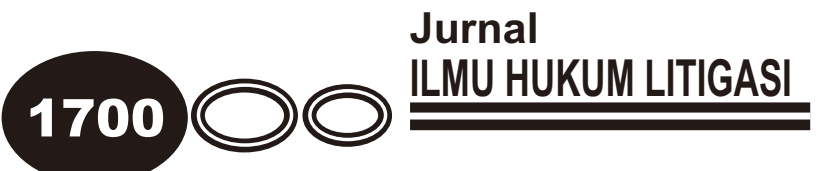

ketentuan perundang-undangan sudah seharusnya dilakukan penataan ulang. Sebelum dilakukan restrukturisasi, terlebih dahulu harus dilakukan adalah identifikasi semua hak atas tanah yang diatur dalam berbagai ketentuan perundang-undangan dan evaluasi implementasi berbagai macam hak atas tanah tersebut, dan rekonseptualisasi hak-hak atas tanah.

Sehubungan dengan hal tersebut maka yang menjadi permasalahan dalam penulisan artikel ini sebagai berikut:

1. Apa sajakah hak-hak atas tanah yang dikenal dalam ketentuan perundangundangan pertanahan nasional sekarang ini dan bagaimanakah batasan masing-masing hak atas tanah tersebut?

2. Bagaimanakah pelaksanaan hak-hak atas tanah tersebut dikaitkan dengan program restrukturisasi penguasaan tanah sebagaimana diamanatkan UUPA?

3. Bagaimana konsep hak-hak atas tanah dalam kerangka pembaharuan hukum tanah nasional?

\section{METODE PENELITIAN}

A. Spesifikasi Penelitian

Spesifikasi penelitian ini merupakan penelitian hukum normatif dan didukung data empiris, karena disamping menelaah ketentuan perundang-undangan, juga mengkaji implementasinya. 
B. Materi Penelitian

Adapun materi penelitian ini berkenaan dengan hak-hak atas tanah yang terdapat dalam ketentuan perundang-undangan dan implementasinya. Data untuk penulisan ini bersumberkan data kepustakaan dan data lapangan.

C. Lokasi Penelitian

Adapun lokasi penelitian untuk perolehan data lapangan adalah Kabupaten Aceh Barat dan Kabupaten Aceh Utara Provinsi Aceh.

D. Teknik Pengumpulan Data

Data kepustakaan diperoleh dengan melakukan kajian terhadap UUPA dan ketentuan perundang-undangan lainnya yang substansinya mengatur bidang pertanahan serta pendapat para ahli yang relevan. Sedangkan data lapangan mengenai pelaksanaan hak-hak atas tanah diperoleh dengan melakukan wawancara dengan berbagai pihak yang terkait.

E. Teknik Pengolahan Data dan Analisis Data

Data kepustakaan dan data lapangan dianalisis dengan menggunakan pendekatan perundang-undangan. 


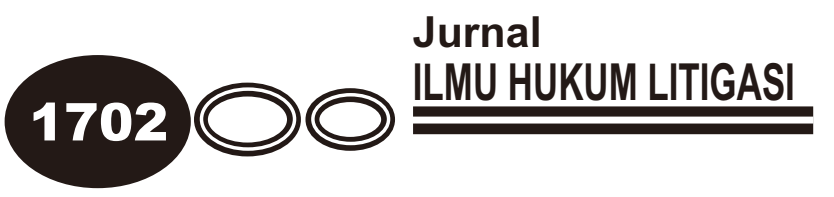

\section{HASIL PENELITIAN DAN ANALISIS}

A. Macam-Macam Hak Atas Tanah Dalam Hukum Tanah Nasional

Pasal 16 ayat (1) UUPA menyebutkan macam-macam hak atas tanah yang dapat dipunyai oleh subjek hukum, yaitu: hak milik; hak guna usaha; hak guna-bangunan; hak pakai; hak sewa; hak membuka tanah; hak memungut-hasil hutan; serta hak-hak lain yang akan ditetapkan dengan undang-undang dan hak-hak yang sifatnya sementara sebagaimana yang disebutkan dalam Pasal 53, yaitu; hak gadai, hak usaha bagi hasil, hak menumpang dan hak sewa tanah. Disamping hak-hak atas tanah sebagaimana tersebut di atas dikenal juga Hak Ulayat (Pasal 3 UUPA), Hak Pengelolaan (PMA 9 Tahun 1965), Hak Milik Atas Satuan Rumah Susun (UU 20 Tahun 2011).

1. Hak Milik

Pengaturan mengenai hak milik terdapat dalam Pasal 20 UUPA sampai dengan Pasal 27 UUPA. Walaupun dalam Pasal 50 ayat (1) UUPA mengamanatkan untuk pengaturan tentang hak milik dalam undang-undang tersen diri tetapi hingga saat ini undang-undang tersebut belum juga lahir namun demikian diperkirakan termasuk dalam salah satu RUU dari 247 RUU yang masuk Prolegnas Tahun 2010 - 2014 (http://www.djpp.depkumham.go.id) dengan judul RUU Hak-hak Atas tanah. 
Pasal 21 ayat (1) dan (2) menyebutkan bahwa yang dapat mempunyai tanah dengan status hak milik adalah Warga Negara Indonesia dan badan-badan hukum tertentu sebagaimana ditentukan dalam PP 38 Tahun 1963 Tentang Penunjukan Badan-Badan Hukum Yang Dapat Mempunyai Hak Milik Atas Tanah.

Hak milik dapat dialihkan, dapat dijadikan jaminan pelunasan utang melalui lembaga hak tanggungan. Sebagai hak atas tanah yang paling kuat maka tanah hak milik dapat didirikan/diberikan hak guna bangunan dan hak pakai, dan sebagai hak atas tanah yang paling penuh maka tanah dengan status hak milik dapat digunakan untuk pertanian dan/atau untuk bangunan. Namun demikian, walaupun merupakan hak atas tanah yang paling kuat dan paling penuh, padanya hak milik melekat prinsip fungsi sosial.

2. Hak Guna Usaha (HGU)

Pengaturan mengenai HGU terdapat dalam berbagai ketentuan perundang-undangan lainnya disamping dalam UUPA. Dalam UUPA diatur dalam Pasal 28 sampai dengan Pasal 34. Peraturan lainnya yang mengatur mengenai HGU meliputi; Peraturan Pemerintah Nomor 40 Tahun 1996 Tentang Hak Guna Usaha, Hak Guna Bangunan dan Hak Pakai Atas Tanah (untuk selanjutnya disebut PP 40 Tahun 1996), Peraturan Menteri Pertanian dan Agraria (PMPA) Nomor 11 Tahun 


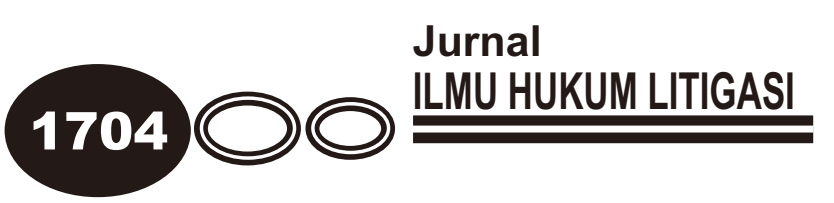

1962 Tentang Ketentuan-ketentuan dan Syarat-syarat Dalam Pemberian Hak Guna Usaha Kepada Pengusaha-pengusaha Swasta Nasional dan Undang-Undang Nomor 25 Tahun 2007 Tentang Penanaman Modal serta peraturan pelaksanaan lainnya.

Hak guna usaha adalah hak mengusahakan tanah negara, dalam jangka waktu tertentu untuk usaha pertanian, perikanan atau peternakan (Pasal 28 ayat 1 UUPA, Pasal 4 PP 40 Tahun 1996). Hak guna usaha diberikan atas tanah yang luasnya paling sedikit 5 hektar, dengan ketentuan bahwa jika luasnya lebih dari 25 hektar maka harus dipunyai oleh badan hukum (Pasal 28 ayat (2) UUPA, Pasal 5 PP 40 Tahun 1996).

Jangka waktu HGU sebagai dimaksudkan dalam Pasal 29 UUPA adalah paling lama 35 tahun dan dapat diperpanjang dengan waktu paling lama 25 tahun dan berdasarkan PP 40 Tahun 1996, masih dimungkinkan untuk dapat diberikan pembaharuan hak apabila jangka waktu pemberian dan perpanjangannya telah berakhir, bahkan berdasarkan Pasal 22 ayat (1) huruf a UU 25 Tahun 2007 bahwa HGU dapat untuk jangka waktu 95 (sembilan puluh lima) tahun dengan cara pemberian dan perpanjangan di muka sekaligus selama 60 (enam puluh) tahun dan pembaharuan hak selama 35 (tiga puluh lima) tahun tetapi berdasarkan Putusan Mahkamah Konstitusi Nomor 21- 
21/PUU-V/2007 bahwa pemberian dan perpanjangan HGU tidak dapat dilakukan dimuka sekaligus melainkan secara bertahap atas permohonan pemohon dan memenuhi syarat.

Disamping jangka waktu yang relatif lama, luasan tanah yang dapat dipunyai dengan HGU tidak terbatas juga dikecualikan dari pembatasan luas maksimun penguasaan tanah pertanian sebagaimana ditentukan dalam UU 56/PRP/1960 tentang Penetapan Luas Tanah Pertanian. Dalam kaitan ini, Ida Nurlinda (2009: 227) menyebutkan bahwa sungguh merupakan suatu kondisi yang tidak adil jika disatu sisi pengusaha dengan kekuatan modalnya dapat menguasai tanah dengan skala yang luas dan dengan jangka waktu yang sangat lama, namun di lain sisi petani kecil sangat sulit memperoleh lahan pertanian.

Hak Guna Usaha terjadi berdasarkan penetapan pemerintah (Pasal 31 UUPA), yaitu diberikan dengan keputusan pemberian hak oleh pejabat yang berwenang sebagaimana ditentukan dalam Peraturan Kepala BPN Nomor 1 Tahun 2011, yang sekarang diganti dengan Peraturan Kepala BPN Nomor 2 Tahun 2013. Pejabat yang berwenang dimaksud adalah pejabat Pemerintah dalam lingkungan BPN, namun untuk areal yang berada dalam wilayah hukum Propinsi Nanggroe Aceh Darussalam maka kewenangan pemberian HGU dan juga HGB berada pada Pemerintah Aceh sebagaimana ditentukan dalam Pasal 214 UU 


\section{Jurnal

Nomor 11 tahun 2006 tentang Pemerintahan Aceh. Hasil penelitian Ilyas Ismail, dkk. (2010: 45-56) menunjukkan bahwa pelaksanaan kewenangan Pemerintah Aceh untuk memberikan HGU dan HGB sebagaimana yang diamanatkan dalam UU Nomor 11 Tahun 2006 belum dapat terlaksana karena belum adanya peraturan pelaksanaan yang terdiri atas; (1) Peraturan Pemerintah yang mengatur tentang batasan kewenangan Pemerintah yang bersifat nasional di Aceh, dan (2) Peraturan Presiden yang mengatur tentang pengalihan BPN menjadi perangkat daerah.

Sengketa atas tanah areal HGU antara pemegang sertifikat HGU dengan masyarakat sekitar merupakan persoalan yang sepertinya tidak pernah kunjung selesai, yang menurut llyas Ismail (2009: 291304) bahwa issu terkait sengketa tersebut selalu klasik yaitu penyerobotan tanah, pemegang HGU menyatakan warga yang menyerobot tanah yang telah diberikan HGU dan warga menyatakan tanah warga yang diserobot untuk diberikan HGU.

Hak guna usaha tidak bersumberkan pada hukum adat karena itu disebut sebagai hak baru dalam sistem UUPA dalam rangka memenuhi kebutuhan masyarakat moderen. Walaupun UUPA dan Penjelasannya menyebutkan bahwa hak guna usaha bukan erfpacht yang dikenal dalam hukum barat (KUH Perdata dan AW) tetapi dilihat 
substansinya kedua hak tersebut (HGU dan erfpacht) mempunyai persamaannya. Persamaan-persamaan tersebut antara lain; (1) hak-hak tersebut hanya dapat diberikan atas tanah negara, (2) hak-hak tersebut merupakan hak atas tanah yang berjangka waktu dan jangka waktunya relatif lebih lama.

3. Hak Guna Bangunan (HGB)

Penjelasan Umum UUPA menyebutkan bahwa HGB juga hak atas tanah ciptaan baru, tidak bersumber pada hukum adat juga tidak berasal dari hukum barat, namun apabila ditinjau substansi aturannya menunjukkan adanya kesamaan dengan Opstal yang dikenal dalam hukum barat, yang berdasarkan UUPA dinyatakan tidak berlaku lagi.

Pasal 35 UUPA menyebutkan bahwa Hak guna bangunan merupakan hak untuk mendirikan dan mempunyai bangunan-bangunan atas tanah yang bukan miliknya sendiri dengan jangka waktu paling lama 30 tahun, yang dapat diperpanjang dengan waktu paling lama 20 tahun dan berdasarkan PP 40 Tahun 1996 masih dimungkinkan untuk dapat diberikan pembaharuan hak apabila jangka waktu pemberian dan perpanjangannya telah berakhir, bahkan berdasarkan Pasal 22 ayat (1) huruf b Undang-Undang No. 25 Tahun 2007 bahwa HGB dapat untuk jangka waktu 80 (delapan puluh) tahun dengan cara pemberian dan perpanjangan di muka sekaligus selama 50 (lima puluh) tahun dan 


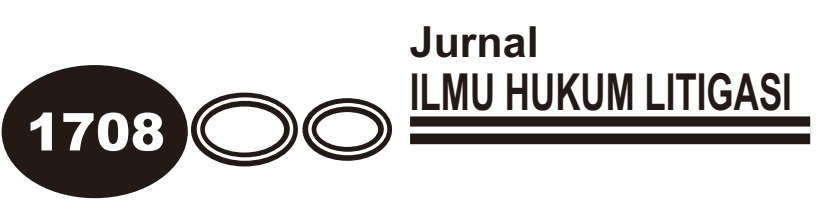

pembaharuan hak selama 30 (tiga puluh) tahun, namun berdasarkan Putusan Mahkamah Konstitusi Nomor 21-21/PUU-V/2007 maka pemberian dan perpanjangan HGB tidak dapat dilakukan dimuka sekaligus tetapi secara bertahap atas permohonan pemohon dan memenuhi syarat.

Berdasarkan ketentuan di atas dapat diketahui bahwa penggunaan tanah yang diberikan dengan HGB adalah untuk bangunan, yang dapat diberikan atas tanah negara, tanah hak pengelolaan dan tanah hak milik. Untuk HGB atas tanah hak milik hanya dikenal pemberian hak dan tidak mengenal perpanjangan hak dan atas kesepakatan para pihak dapat diperbaharui dengan pemberian HGB baru berdasarkan perjanjian baru.

4. Hak Pakai

Pasal 41 UUPA pada intinya disebutkan bahwa Hak pakai merupakan hak untuk menggunakan dan/atau memungut hasil atas tanah negara atau tanah milik orang lain, untuk jangka waktu tertentu atau selama tanah itu digunakan untuk keperluan tertentu, baik dengan pembayaran atau Cuma-Cuma, dan berdasarkan Pasal 41 PP No. 40 Tahun 1996 bahwa hak pakai dapat diberikan atas hak pengelolaan.

Hak pakai merupakan satu-satunya hak atas tanah yang dapat dipunyai Warga Negara Asing dan Badan Hukum Asing, di samping 
dapat dipunyai oleh Warga Negara Indonesia dan Badan Hukum Indonesia serta institusi publik. Hanya saja pengaturan mengenai hak pakai bagi orang asing sebagaimana di atur dalam PP 41 Tahun 1996 belum komprehensif karena masih terbatas pada pemilikan hak pakai untuk tempat hunian dan hanya untuk subjek orang perorangan, karena itu menurut Maria SW. Sumardjono (2007: 67) dalam kerangka penyempurnaanya aturan tersebut perlu diperluas ruang lingkup pengaturanya baik berkenaan subjek maupun objeknya, sehingga lingkup pengaturannya tidak hanya meliputi rumah tempat tinggal, tetapi meliputi hak atas tanah beserta bangunan untuk hunian maupun bukan hunian, dan subjek hak tidak hanya WNA namun juga badan hukum asing.

Hak Guna Usaha dan HGB yang hanya mengenal satu pola jangka waktu yaitu bersifat limitatif sedangkan jangka waktu hak pakai mengenal dua pola jangka waktu yaitu "jangka waktu tertentu yang bersifat limitatif" yang diperuntukkan bagi subjek perorangan dan badan hukum (privat) dan jangka waktu "selama dipergunakan" untuk keperluan pelaksanaan tugas yang diperuntukan bagi subjek institusi publik.

Jangka waktu tertentu sebagai mana dimaksud dalam ketentuan di atas tidak ditetapkan secara tegas dalam UUPA tetapi terdapat dalam 


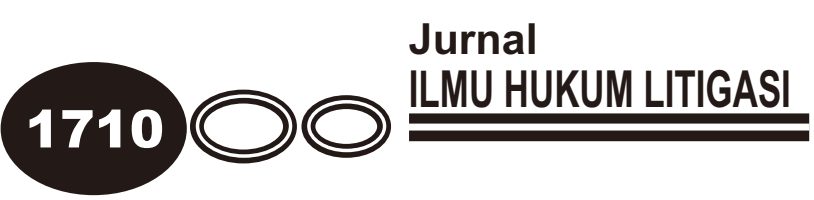

berbagai ketentuan perundang-undangan dibawahnya yang masingmasing ketentuan menetapkan jangka waktu yang berbeda. Berdasarkan PP No. 40 Tahun 1996 bahwa hak pakai diberikan untuk jangka waktu paling lama 25 (dua puluh lima) tahun dan dapat diperpanjang paling lama 20 (dua puluh) tahun serta dapat diperbaharui. Berdasarkan Pasal 22 ayat (1) huruf c Undang-Undang No. 25 Tahun 2007 bahwa jangka waktu hak pakai mencapai 70 (tujuh puluh) tahun dengan cara pemberian dan perpanjangan di muka sekaligus selama 45 (empat puluh lima) tahun dan pembaharuan hak selama 25 (dua puluh lima) tahun, namun berdasarkan Putusan Mahkamah Konstitusi Nomor 2121/PUU-V/2007 maka pemberian dan perpanjangan hak pakai tidak dapat dilakukan dimuka sekaligus tetapi secara bertahap atas permohonan pemohon dan memenuhi syarat.

5. Hak Sewa

Hak sewa dalam sistem UUPA dibedakan antara hak sewa tanah bangunan dan hak sewa tanah pertanian. Hak sewa tanah bangunan diatur dalam Pasal 16 ayat (1) huruf e dan Pasal 44 UUPA, sedangkan hak sewa tanah pertanian diatur dalam Pasal 53 UUPA yang merupakan salah satu hak atas tanah yang bersifat sementara. Hak sewa tanah bangunan dan hak sewa tanah pertanian merupakan hak atas 
tanah yang diberikan atas tanah milik orang lain, tidak dapat diberikan atas tanah negara.

Penjelasan UUPA menyebutkan bahwa hak sewa merupakan hak pakai yang mempunyai sifat-sifat khusus karena itu diatur tersendiri dan hanya disediakan untuk bangunan sedangkan hak sewa untuk pertanian merupakan salah satu hak atas tanah yang bersifat sementara dan akan dihapuskan karena dianggap mengandung unsur-unsur pemerasan.

6. Hak Membuka Tanah Dan Hak Memungut Hasil Hutan

Pasal 46 ayat (1) UUPA menyebutkan bahwa Hak membuka tanah dan memungut hasil hutan hanya dapat dipunyai oleh warga negara Indonesia dan diatur dengan Peraturan Pemerintah. Lebih lanjut dalam ayat (2) disebutkan bahwa dengan mempergunakan hak memungut hasil hutan secara sah tidak dengan sendirinya diperoleh hak milik atas tanah itu.

Sejauh yang dapat diketahui hingga saat ini belum ada peraturan pemerintah yang secara khusus mengatur mengenai hak membuka tanah dan hak memungut hasil hutan. Mengenai hak membuka tanah pernah diatur dalam Peraturan Menteri Dalam Negeri 6 Tahun 1972 Tentang Pelimpahan Kewenangan Pemberian Hak Atas Tanah yang kemudian dicabut dan dinyatakan tidak berlaku berdasarkan 


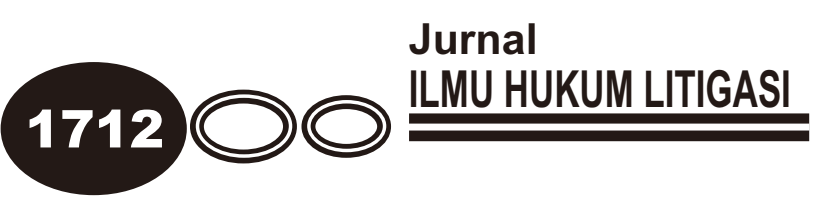

PMNA/KBPN 3/1999 tentang Pelimpahan Kewenangan Pemberian Dan Pembatalan Keputusan Pemberian Hak Atas Tanah Negara yang kemudian telah diganti beberapa dan terakhir dengan PKBPN 2/2013 hanya saja dalam dua peraturan terakhir ini tidak mengatur lagi mengenai hak membuka tanah. Kewenangan pemberian izin membuka tanah dilaksanakan oleh Pemerintah Kabuapten/Kota sebagaimana ditentukan Keppres 34 Tahun 2003 tentang Kebijakan Nasional Bidang Pertanahan.

7. Hak-Hak Yang Bersifat Sementara

Pasal 53 ayat (1) menyebutkan "hak-hak yang sifatnya sementara sebagaimana yang dimaksud dalam Pasal 16 ayat (1) huruf h, ialah hak gadai, hak usaha bagi hasil, hak menumpang dan hak sewa tanah pertanian diatur untuk membatasi sifat-sifatnya yang bertentangan dengan undang-undang ini dan hak-hak tersebut diusahakan hapusnya didalam waktu yang singkat".

Hak-hak atas tanah tersebut dianggap mengandung unsur-unsur pemerasan oleh orang-orang yang mempunyai kedudukan ekonomi lebih kuat terhadap orang-orang yang mempunyai kedudukan ekonomi lemah. Karena itu pengaturan dalam UUPA, Undang-Undang No. 56/PRP/1960 dan Undang-Undang No. 2 Tahun 1960 dan peraturan lainnya dimaksudkan untuk membatasi unsur pemerasan dan 
diusahakan untuk dihapuskan hak-hak atas tanah tersebut. Sejauh yang dapat diketahui hingga saat ini belum ada ketentuan perundangundangan sebagai pelaksanaan UUPA yang menentukan penghapusan hak-hak atas tanah yang sifatnya sementara tersebut.

8. Hak Ulayat

UUPA mengakui hak ulayat sepanjang menurut kenyataannya masih ada dan pelaksanaannya sesuai dengan kepentingan nasional dan negara, mengindahkan prinsip persatuan bangsa serta tidak bertentangan dengan ketentuan perundang-undangan.

Pasal 2 ayat (2) PMNA/KBPN No. 5 Tahun 1999 menyebutkan 3 (tiga) kriteria penentu adanya hak ulayat, yaitu (1) terdapat sekelompok orang yang masih merasa terikat oleh tatanan hukum adatnya sebagai warga bersama suatu persekutuan hukum tertentu, yang mengakui dan menerapkan ketentuan-ketentuan persekutuan tersebut dalam kehidupannya sehari-hari; (2) terdapat tanah ulayat tertentu yang menjadi lingkungan hidup para warga persekutuan hukum tersebut dan tempatnya mengambil keperluan hidupnya sehari-hari; dan (3) terdapat tatanan hukum adat mengenai pengurusan, penguasaan dan penggunaan tanah ulayat yang berlaku dan ditaati oleh para warga persekutuan hukum tersebut. 


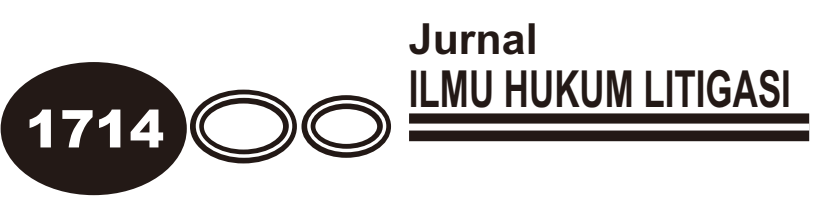

Lebih lanjut dalam Pasal 5 PMNA/KBPN No. 5 Tahun 1999 diebutkan bahwa untuk menentukan masih ada atau tidaknya hak ulay at dari suatu masyarakat hukum berdasarkan tiga kriteria tersebut harus dilakukan penelitian oleh pemerintah daerah dengan mengikutsertakan pakar hukum adat, masyarakat hukum adat setempat, LSM dan instansi yang mengelola sumber daya alam.

Maria SW Sumardjono (2008: 172) menyebutkan bahwa dalam konsepsi hukum tanah nasional, pembicaraan tentang hak ulayat tidak hanya mengenai tanahnya saja melainkan meliputi segala isinya, termasuk di dalamnya hutan. Dari aspek statusnya juga, tanah ulayat merupakan entitas tersendiri yang harus dibedakan dengan tanah negara dan tanah hak. Karena itu konsepsi yang berkaitan dengan hak ulayat perlu dijadikan pedoman dalam pelaksanaan penelitian untuk penentuan ada atau tidaknya hak ulayat.

9. Hak Pengelolaan (HPL)

Istilah hak pengelolaan tidak terdapat dalam UUPA, kecuali prasa "pelaksanaan $\mathrm{HMN}$ dapat dikuasakan kepada daerah-daerah swatantra dan masyarakat-masyarakat hukum adat..." (Pasal 2 ayat 4), dan prasa "...negara dapat memberikan tanah .... kepada seseorang atau badan hukum dengan sesuatu hak .... atau memberikannya dalam pengelolaan kepada sesuatu badan penguasa (departemen, jawatan atau 
daerah swatantra) untuk dipergunakan bagi pelaksanaan tugasnya masing-masing" (Penjelasan Umum II angka 2).

Berdasarkan PMA No. 9 Tahun 1965 bahwa tanah-tanah yang dikuasai oleh departemen-departemen, direktorat-direktorat dan daerah-daerah swatantra dikonversi menjadi hak pakai apabila tanahtanah tersebut hanya dipergunakan untuk kepentingan instansi-instansi itu sendiri atau dikonversi menjadi hak pengelolaan apabila disamping dipergunakan untuk kepentingan instansi-instansi itu sendiri juga dimaksudkan untuk dapat diberikan dengan sesuatu hak kepada pihak ketiga. Di samping berdasarkan konversi dari hak penguasaan, hak pengelolaan juga dapat lahir berdasarkan mekanisme pemberian hak sebagaimna diatur dalam PMNA/KBPN Nomor 9 Tahun 1999.

Menurut Boedi Harsono (2005: 281) berdasarkan kewenangan yang diberikan oleh ketentuan perundang-undangan kepada pemegang hak pengelolaan menunjukkan bahwa hak pengelolaan merupakan gempilan hak menguasai negara yang dimaksudkan Pasal 2 UUPA, bahkan Maria SW Sumardjono (2008: 213) secara tegas menyebutkan bahwa HPL bukanlah hak atas tanah sebagaimana hak milik, HGU, HGB atau Hak Pakai yang diatur dalam UUPA. 


\section{Jurnal

Berdasarkan draf RUU tentang Pertanahan (draf 27 Maret 2013) bahwa hak pengelolaan diatur dalam Pasal 5 sampai dengan Pasal 7, yang inti pengaturannya masih mirip seperti aturan-aturan yang mengatur hak pengelolaan sebelumnya terutama mengenai kewenangan pemegang haknya yang merupakan bagian dari kewenangan negara sebagai pemegang Hak Menguasai, sebagaimana disebut dalam Pasal 5 ayat (2) draf RUU Pertanahan "Hak Pengelolaan memberikan kewenangan untuk: (a) menyusun rencana peruntukan, penggunaan, dan pemanfaatan tanahnya; dan (b) menyerahkan pemanfaatan bagianbagian tanah Hak Pengelolaan tersebut kepada pihak ketiga". Disamping itu dalam Pasal 19 Draf RUU Pertanahan memang hanya menentukan lima macam hak atas tanah yaitu; Hak Milik, Hak Guna Usaha, Hak Guna Bangunan, Hak Pakai, dan Hak Sewa Untuk Bangunan.

\section{B. Pelaksanaan Hak-Hak Atas Tanah}

Uraian mengenai pelaksanaan hak-hak atas tanah dikelompokkan menjadi dua golongan, yaitu hak-hak atas tanah yang terdaftar dan hak-hak atas tanah yang tidak terdaftar pada Kantor Pertanahan. Hak-hak atas tanah yang terdaftar terdiri atas; hak milik, HGU, HGB, Hak Pakai dan Hak Pengelolaan. Sedangkan hak-hak atas tanah yang tidak terdaftar terdiri atas; 
hak membuka tanah dan hak memungut hasil hutan, hak-hak atas tanah yang, bersifat sementara, dan hak ulayat.

1. Hak Milik, HGU, HGB Dan Hak Pakai Serta HPL

Berdasarkan data yang diperoleh pada Kantor Pertanahan Kabupaten Aceh Barat dan Kantor Pertanahan Kabupaten Aceh Barat serta Kanwil BPN Propinsi Aceh dapat diketahui bahwa hak-hak atas tanah yang telah terdaftar adalah sebagaimana tercantum pada Tabel 1 dan Tabel 2.

Tabel 1

Hak Atas Tanah Yang Terdaftar Berdasarkan Jumlah Bidang

\begin{tabular}{|c|c|c|c|c|c|c|}
\hline \multirow[b]{2}{*}{ No } & \multirow[b]{2}{*}{ Kabupaten } & \multicolumn{5}{|c|}{ Hak Atas Tanah } \\
\hline & & $\begin{array}{l}\text { Hak milik } \\
\text { (bdg) }\end{array}$ & $\begin{array}{l}\text { HGU } \\
\text { (bdg) }\end{array}$ & $\begin{array}{l}\text { HGB } \\
\text { (bdg) }\end{array}$ & $\begin{array}{l}\text { Hak } \\
\text { Pakai } \\
\text { (bdg) }\end{array}$ & $\begin{array}{l}\text { HPL } \\
\text { (bdg) }\end{array}$ \\
\hline 1. & Aceh Barat & 53.071 & 11 & 254 & 495 & 3 \\
\hline 2. & Aceh Utara & 58.473 & 21 & 505 & 1.017 & 15 \\
\hline \multicolumn{2}{|c|}{ Jumlah Bidang } & 111.544 & 33 & 759 & 1.512 & 18 \\
\hline
\end{tabular}

Sumber: Kantor Pertanahan Kabuapten Aceh Barat, Kantor Pertanahan Kab. Aceh Utara dan Kantor Wilayah BPN Propinsi Aceh, setelah diolah, 2011. 


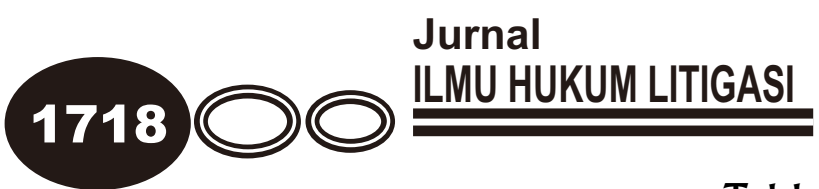

Table 2

Hak Atas Tanah Yang Terdaftar Berdasarkan Jumlah Luas

\begin{tabular}{|c|l|cc|ccc|}
\hline \multirow{2}{*}{ No } & \multirow{6}{*}{ Kabupaten } & $\begin{array}{c}\text { Hak milik } \\
\text { (ha) }\end{array}$ & $\begin{array}{c}\text { HGU } \\
\text { (ha) }\end{array}$ & $\begin{array}{c}\text { HGB } \\
\text { (ha) }\end{array}$ & $\begin{array}{c}\text { Hak Pakai } \\
\text { (ha) }\end{array}$ & $\begin{array}{c}\text { HPL } \\
\text { (ha) }\end{array}$ \\
\cline { 3 - 7 } & & 868,10 & $36.556,58$ & 16,36 & $12.893,55$ & $56.738,50$ \\
\hline 1. & Aceh Barat & $32.741,95$ & $30.994,36$ & $1.823,85$ & $1.154,75$ & $6.632,58$ \\
\hline 2. & Aceh Utara & $33.610,05$ & $67.550,94$ & $1.840,21$ & $14.048,30$ & $63.371,08$ \\
\hline & Jumlah Luas & & & & & \\
\hline
\end{tabular}

Sumber: Kantor Pertanahan Kabuapten Aceh Barat, Kantor Pertanahan Kab. Aceh Utara dan Kantor Wilayah BPN Propinsi Aceh, setelah diolah, 2011.

Berdasarkan jumlah bidang tanah yang telah terdaftar menunjukkan bahwa tanah dengan status Hak Milik merupakan hak atas tanah yang paling tinggi jumlahnya dibandingkan dengan hak-hak atas tanah lainnya, tetapi apabila didasarkan pada jumlah luasnya maka tanah dengan status HGU merupakan hak atas tanah yang paling tinggi jumlah luasnya dibandingkan dengan hak-hak atas tanah lainnya.

Walaupun jumlah bidang yang terdaftar menempati urutan tertinggi tidak berarti bahwa semua bidang tanah dengan status hak milik telah terdaftar, bahkan di 4 (empat) kecamatan yaitu Sungai Mas, Pantee Ceuremen, Woyla Barat dan. Woyla Timur Kebupaten Aceh Barat tidak satupun bidang tanah yang terdaftar dengan status hak milik, walaupun demikian hasil wawancara dengan nara sumber 
(HM. Yasir, Tokoh Masyarakat di Desa Suak Raya, Kecamatan Johan Pahlawan, Kab. Aceh Barat, wawancara 12 Juli 2011; dan TM. Idris Thaib, Imum Mukim Buloh Blang Ara Kec. Kuta Makmur Kabupaten Aceh Utara, wawancara, 27 Juli 2011) menyebutkan bahwa sebagian besar bidang-bidang tanah tersebut terutama yang berada disekitar pemukiman telah diusahakan secara turun temurun baik yang digunakan sebagai lahan pertanian maupun yang digunakan sebagai tempat tinggal.

Walaupun jumlah persilnya HGU lebih kecil dari pada hak milik namun jumlah luasnya lebih besar. Hal ini disebabkan peluang yang diberikan ketentuan perundang-undangan yang tidak membatasi luas maksimun tanah dengan status HGU yang dipunyai oleh badan hukum.

Hak Guna Bangunan sebagaimana telah disebut terdahulu merupakan hak atas tanah yang dapat dipunyai oleh orang perorangan WNI dan Badan Hukum Indonesia (BHI) untuk mendirikan dan mempunyai bangunan, demikian juga hak pakai, hanya saja subjek dan penggunaan tanah dengan status hak pakai lebih luas dibandingkan dengan HGB. Hak pakai disamping dapat dipunyai WNI dan BHI juga dapat dipunyai oleh WNA dan Badan Hukum Asing (BHA) yang berkedudukan di Indonesia. Selain dari itu memungkinkan juga 


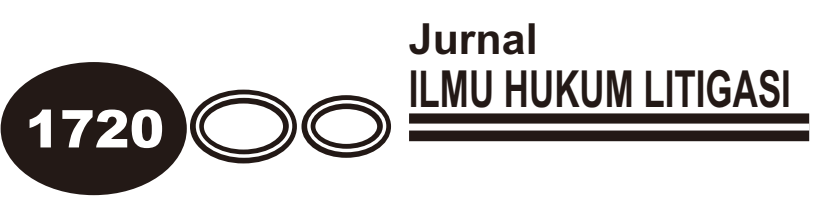

dipunyai oleh institusi publik (pemerintah, pemerintah daerah, perwakilan negara asing dan perwakilan badan internasional). Apabila ditinjau dari aspek penggunaan tanahnya juga lebih luas dibandingkan dengan HGB atau sama dengan penggunaan tanah dengan status hak milik, yaitu dapat untuk penggunaan dibidang pertanian dan juga dapat untuk bidang nonpertanian. Karena itu dapat dipahami bahwa substansi hak pakai telah mengakomodir substansi HGU dan HGB.

Hak pengelolaan merupakan hak penguasaan atas tanah yang unik. Dikatakan unik karena penguasaan tanah dengan status hak pengelolaan memungkinkan pemegang haknya untuk memberikan bagian-bagian tanah hak pengelolaan dengan suatu hak tertentu (HGB dan Hak Pakai) kepada pihak lain disamping menggunakannya untuk kepentingan pelaksanaan tugas institusi pemegang hak, namun demikian ketentuan tersebut tidak konsisten dengan prinsip hak menguasai negara, yang pada dasarnya kewenangan pemberian hak atas tanah berada pada negara atau pemerintah sebagai pemegang hak menguasai negara bukan sebagai subyek hak atas tanah.

\subsection{Hak Membuka Tanah Dan Hak Memungut Hasil Hutan}

Hak membuka tanah dan hak memungut hasil hutan pada dasarnya belum menjadi hak atas tanah tetapi permulaan perlekatan hubungan hukum yang apabila dilakukan pengusahaan secara terus 
menerus sesuai kaedah-kaedah hukum adat potensial untuk menjadi suatu hak atas tanah berupa hak garap bahkan dapat menjadi hak milik. Menurut Tgk. Ismail, Tokoh Masyarakat Desa Lhok Jok, Kecamatan Kuta Makmur, Kab. Aceh Utara, wawancara, 27 Juli 2011 dan HM. Yasir, Tokoh Masyarakat Desa Suak Raya, Kecamatan Johan Pahlawan, Kab. Aceh Barat, wawancara, 12 Juli 2011 bahwa saat ini dapat dikatakan hampir tidak ada lagi lahan disekitar perkampungan warga masyarakat yang belum dikuasai oleh seseorang atau suatu badan hukum, karena itu hampir tidak ada lagi peluang untuk mendapatkan hak membuka hutan dan memungut hasil hutan.

\subsection{Hak-Hak Yang Bersifat Sementara}

Hak-hak atas tanah yang bersifat sementara yang masih dominan dalam praktek penguasaan tanah selama ini adalah hak gadai dan hak usaha bagi hasil. Hak-hak tersebut telah ada dalam praktek penguasaan tanah sejak lama. Menurut Teuku Saifuddin, Tokoh Masyarakat Buloh Blang Ara, Kec. Kuta Makmur Kab. Aceh Utara, wawancara, 28 Juli 2011 , bahwa ada dua model gadai tanah; (1) gadai tanah yang semua hasil dari tanah tersebut menjadi milik pembeli gadai, dan tanah tersebut akan dikembalikan kepada pemiliknya ketika ditebus; (2) gadai tanah yang hasil dari tanah tersebut akan diperhitungkan sebagai bagian harga gadai sehingga 


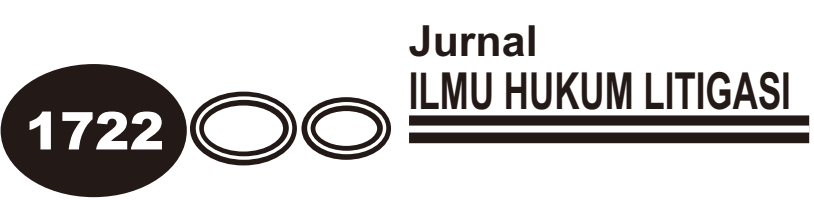

harga tebusan tidak seperti harga jual gadai tetapi tergantung pada hasil tanah tersebut dan lamanya waktu gadai berlangsung.

Demikian juga halnya dengan hak usaha bagi hasil yang masih dipraktekkan oleh warga masyarakat khususnya hak usaha bagi hasil tanah sawah. Walaupun Undang-Undang No. 2 Tahun 1960 telah mengatur mengenai bentuk, imbangan bagi hasil dan jangka waktu namun dalam prakteknya cenderung dilaksanakan atas dasar kesepakatan para pihak, yang cenderung lebih menguntungkan pemilik tanah.

2.3. Hak Ulayat

Menentukan ada atau tidak adanya hak ulayat harus dilakukan penelitian sebagaimana diamanatkan PMNA/KBPN 5 Tahun 1999, namun demikian karena kenyataannya hampir semua bidang tanah di sekitar perkampungan telah melekat hak perorangan maka hal tersebut mengindikasikan bahwa hak ulayat telah melemah.

C. Konsepsi Hak Atas Tanah

Berdasarkan hasil penelitian yang menunjukan bahwa hak atas tanah yang terdaftar meliputi; Hak Milik, HGU, HGB, Hak Pakai dan HPL maka pembahasan konsepsi hak atas tanah dibatasi pada hak-hak yang terdaftar tersebut. 
Terkait dengan konsep hak milik, Aslan Noor (2006: 318) membedakan tiga konsep hak milik, yaitu; (1) konsep hak atas tanah milik individu (perorangan), (2) konsep hak atas tanah milik badan hukum privat (badan hukum perdata), dan (3) konsep hak atas tanah milik publik (instansi pemerintah). Dalam perundang-undangan di bidang pertanahan memang dimungkinkan badan hukum (privat) tertentu untuk mempunyai hak milik bahkan badan-badan sosial keagamaan sebagaimana ditentukan dalam Pasal 49 UUPA. Terhadap masing-masing jenis hak milik tersebut diperlukan pengaturan lebih tegas karena mempunyai karakteristik tersendiri.

Hak Guna Usaha dan HGB merupakan konsep hak atas tanah yang tidak bersumberkan pada hukum adat namun penciptaannya dipandang dapat mengakomodir kebutuhan masyarakat modern. Namun demikian Herman Soesangobeng (2012: 282) menyebutkan bahwa konsep HGU dan HGB mirip dengan konsep "erfpacht" dan "recht van opstal" yang berkonsepsi keagrarian Burgerlijke Wetboek/KUH Perdata yang telah dinyatakan tidak berlaku oleh UUPA. Karena itu HGU dan HGB harus diubah menjadi hak pakai menurut filosofi, asas dan ajaran hukum pertanahan adat Indonesia yang diterjemahkan dan ditafsirkan secara kontemporer. 


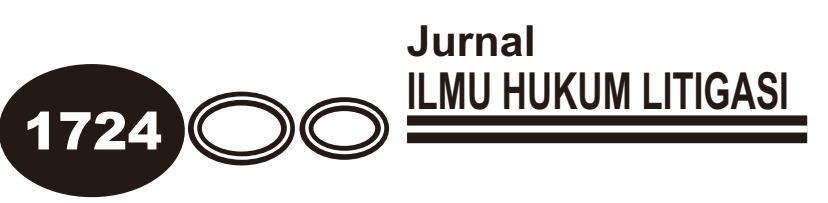

Kenyataan mengindikasikan bahwa penguasaan tanah dengan status HGU cenderung menimbulkan ketimpangan penguasaan tanah karena diberikan peluang penguasaan tanah dengan luasan yang relatif tidak terbatas. Karena itu pembatasan luasan maksimum dengan memperhatikan kebutuhan dan ketersediaan lahan petanian merupakan salah satu alternatif disamping alternatif mengubah hak tersebut menjadi hak pakai.

Pengaturan hak pakai dalam ketentuan perundang-undanga dipandang masih relefan, disamping bersumberkan pada konsepsi hukum pertanahan adat juga responsif terhadap kebutuhan tanah bagi institusi publik dan orang asing yang berada di Indonesia. Hanya saja sebagian pihak masih memandang bahwa hak pakai merupakan hak atas tanah yang kedudukannya lebih rendah dibandingkan dengan HGU dan HGB.

Hak Pengelolaan dipandang sebagai suatu hak atas tanah yang unik, mendua antara sebagai hak atas tanah atau hanya kewenangan yang bersifat publik. Karena itu dipandang perlu ditinjau kembali. Apabila ingin diposisikan sebagai hak atas tanah maka perlu ditempatkan dalam struktur hak atas tanah yang mempunyai kesamaan konsep sebagai suatu hak atas tanah dan sekaligus terdapat perbedaan antara satu hak dengan hak lainnya. Apabila ditetapkan sebagai kewenanagan yang bersifat publik maka pengaturannya harus konsisten dengan konsep hak menguasai negara. 


\section{KESIMPULAN DAN SARAN}

\section{A. Kesimpulan}

1. Paling tidak dalam ketentuan perundang-undangan terdapat 13 (tiga belas) macam hak atas tanah, yaitu Hak Milik, Hak Guna Usaha, Hak Guna Bangunan, Hak Pakai, Hak Sewa, Hak Membuka Tanah, Hak Memungut Hasil Hutan, Hak Gadai, Hak Usaha Bagi Hasil, Hak Sewa Tanah Pertanian, Hak Menumpang, dan Hak Ulayat serta Hak Pengelolaan. Keberadaan HGU, HGB dan Hak Pengelolaan perlu ditinjau kembali. Dalam Draf RUU tentang Pertanahan (27 Maret 2013) tidak lagi mengatur hak membuka tanah, hak memungut hasil hutan dan hak-hak yang bersifat sementara (hak gadai, hak usaha bagi hasil, hak menumpang dan hak hak sewa tanah pertanian).

2. Ketentuan perundangan-undangan yang memberikan peluang penguasaan tanah HGU dengan luasan yang relatif tidak terbatas, tidak sejalan dengan prinsip pemerataan penguasaan tanah. Terjadi penumpukan tanah pertanian pada sebagian kecil subjek sedangkan sebagian besar subjek lainnya (petani) tidak mempunyai tanah pertanian dengan luasan yang cukup untuk memenuhi kebutuhan hidupnya. Keberadaan hak gadai dan hak usaha bagi hasil masih cenderung terjadinya penindasan terhadap petani penggarap. 


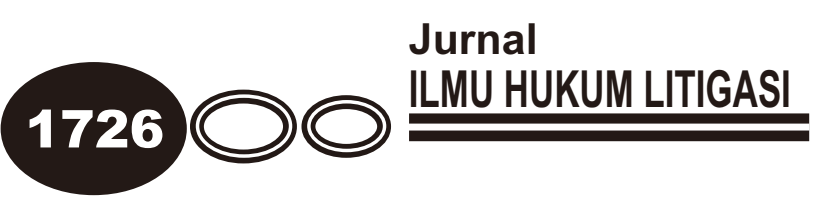

3. Konsepsi Hak Milik yang merupakan hak yang paling kuat perlu pengaturan secara komprerensih baik menyangkut subyek, obyek maupun hak dan kewajiban yang melekat pada subjek hak. Terhadap HGU dan HGB dapat dipilih tetap dipertahankan tetapi perlu adanya pembatasan luas maksimum yang memungkin adanya peluang pemerataan penguasaan tanah secara berkeadilan atau dihapuskan yang kemudian diakomodasikan dalam konsep Hak Pakai. Terhadap HPL diperlukan adanya ketegasan apakah merupakan hak atas tanah atau merupakan bagian dari Hak Menguasai Negara, apapun konsep yang dipilih perlu konsistensi pengaturannya.

B. Saran

1. Agar terdapat pemerataan penguasaan tanah yang berkeadilan dan pengusahaannya dapat optimal dan berkelanjutan maka perlu penataan kembali struktur hak-hak atas tanah, antara lain dengan meninjau kembali keberadaan HGU, HGB dan Hak Pengelolaan. Draf RUU tentang Pertanahan (27 Maret 2013) yang telah membuka peluang untuk reformulasi hak atas tanah diperlukan kajian yang komprehensif sebelum ditetapkan sebagai hukum positif sehingga pengaturan mengenai hak-hak atas tanah di masa mendatang dapat mengakomodir berbagai kebutuhan terhadap tanah secara berkeadilan. 
Volume 14

No. 1 April 2013

1627

2. Diharapkan juga Pemerintah dapat melakukan langkah-langkah konkrit dalam upaya penghapusan lembaga hak gadai dan hak usaha bagi hasil sekaligus menetapkan solusi alternatif pengganti hak atas tanah tersebut, sehingga dalam hal pengusahaan tanah oleh bukan pemiliknya tidak lagi mengandung unsur-unsur pemerasan. 


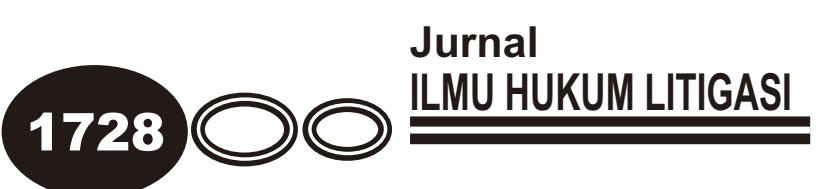

\section{DAFTAR PUSTAKA}

Aslan Noor, 2006, Konsep Hak Milik Atas Tanah Bagi Bangsa Indonesia Ditinjau Dari Ajaran Hak Asasi Manusia, Bandung, Mandar Maju.

Boedi Harsono, 2005, Hukum Agraria Indonesia, Sejarah Pembentukan UndangUndang Pokok Agraria, Isi dan Pelaksanaanya, Jakarta, Djambatan.

Herman Soesangobeng, 2012, Filosofi, Asas, Ajaran, Teori Hukum Pertanahan dan Agraria, Yogyakarta, STPN Press.

Ida Nurlinda, 2009, Prinsip-Prinsip Pembaruan Agraria, Perspektif Hukum, Jakarta, Rajawali Pers.

Maria SW. Sumardjono, 2008, Tanah Dalam Perspektif Hak Ekonomi, Sosial dan Budaya, Jakarta, Penerbit Buku Kompas.

Maria SW. Sumardjono, 2007, Alternatif Kebijakan Pengaturan Hak Atas Tanah Beserta Bangunan Bagi Warga Negara Asing dan Badan Hukum Asing, Jakarta, Penerbit Buku Kompas.

\section{JURNAL}

Ilyas Ismail, 2009, Tipologi Sengketa Tanah dan Alternatif Penyelesaiaannya, KANUN Jurnal IImu Hukum KANUN, Tahun IX, No. 47.

Ilyas Ismail, dkk., 2010, Desentralisasi Kewenangan Bidang Pertanahan Berdasarkan Undang-Undang Nomor 11 Tahun 2006, Jurnal Media Hukum, Vol. 17, No. 1 . 
Volume 14

No. 1 April 2013

1629

\section{WEBSITE}

Kemenkumham, Dirjen Peraturan Perundang-undangan, 2010, Prolegnas 20102014, http://www.djpp.depkumham.go.id/prolegnas-2010-2014, diunduh tanggal 19 September 2011 Jam 07:05 WIB. 